\title{
Long-term efficacy and safety of sirolimus therapy in patients with lymphangioleiomyomatosis
}

Siqi Hu $u^{1,2,3}$, Xiuxiu Wu ${ }^{1,4}$, Wenshuai $\mathrm{Xu}^{1}$, Xinlun Tian ${ }^{1,5}$, Yanli Yang ${ }^{1,5}$, Shao-Ting Wang ${ }^{1,5}$, Song Liu ${ }^{5,6}$, Xingxiang $X u^{2}$ and Kai-Feng $X u^{1,5^{*}}$ (D)

\begin{abstract}
Background: Sirolimus has been confirmed to be effective for lymphangioleiomyomatosis (LAM), a rare multisystem neoplastic disease in women. The long-term effects of sirolimus treatment for LAM, however, are largely unknown. We aimed to analyze the long-term efficacy and safety of sirolimus therapy for LAM with 4-year follow-up.

Methods: In total, 142 sporadic LAM patients who took sirolimus for 1-4 years were retrospectively enrolled for this analysis. The variables used for analysis included pulmonary function tests, arterial blood gas analysis, 6-min walking distance (6MWD), St. George's Respiratory Questionnaires (SGRQ) and serum vascular endothelial growth factor-D (VEGF-D) levels before and after the initiation of sirolimus therapy. The rates of change (slope) in those variables were calculated, and adverse events were also analyzed.

Results: In total, 122, 83, 60 and 32 patients out of 142 were followed for 1, 2, 3 and 4 years respectively. Sirolimus treatment improved the change rate in forced expiratory volume in 1 second $\left(\mathrm{FEV}_{1}\right)$ and forced vital capacity (FVC) compared with the data before treatment $\left(\mathrm{FEV}_{1},-10 \pm 15 \mathrm{vs} .-178 \pm 36 \mathrm{ml} / \mathrm{y}, P<0.001\right.$ and FVC, $54 \pm 22 \mathrm{vs} .-72 \pm 68$ $\mathrm{ml} / \mathrm{y}, P<0.05)$. In comparison to the baseline measurements, significant improvements were observed in $\mathrm{FEV}_{1}$ at the first year; FVC at 1-2 years; arterial oxygen levels, 6MWD, and SGRQ at 1-3 years; and VEGF-D at 1-4 years. Overall, all variables stabilized or improved during the 4 years of observation. Adverse events related to sirolimus were mild.

Conclusion: Sirolimus therapy is effective at improving or stabilizing pulmonary function, oxygen levels, exercise capacity, and quality of life in patients with LAM for up to 4 years. VEGF-D is maintained at a lower level for 4 years after treatment. Adverse events related to sirolimus were mild.
\end{abstract}

Keywords: Lymphangioleiomyomatosis, Sirolimus, Pulmonary function

\section{Background}

Lymphangioleiomyomatosis (LAM) is a rare multisystem neoplastic disease that is characterized by cystic lung destruction, angiomyolipoma and lymphangioleiomyomas $[1,2]$. LAM may occur sporadically, or in adults with tuberous sclerosis complex [1]. Cystic remodeling in the lungs compromises lung function, resulting in progressive dyspnea, and finally respiratory failure [3].

\footnotetext{
* Correspondence: kaifeng.xu@gmail.com

'Department of Pulmonary and Critical Care Medicine, Peking Union Medical College Hospital, Chinese Academy of Medical Sciences, Peking Union Medical College, Beijing 100730, China

${ }^{5}$ Rare Diseases Research Center, Chinese Academy of Medical Sciences, Beijing, China

Full list of author information is available at the end of the article
}

Sirolimus (rapamycin) has been confirmed to be effective for the treatment of LAM $[4,5]$. In our previous report, sirolimus was shown to improve lung function, arterial oxygen levels, 6 min walking distance (6MWD), St George Respiratory questionnaire (SGRQ) scores and vascular endothelial growth factor (VEGF-D) levels [6]. However, the long-term effects of sirolimus are unclear. Several studies included data on sirolimus treatment over a 2-years period [7-12]. Taveria-DaSilva et al. [8] reported a study in which 44 patients were treated with sirolimus alone, the changes of predicted values of $\mathrm{FEV}_{1}$ and DLCO were $-1.7 \% \pm 0.1 \%$ and $-2.2 \% \pm 0.1 \%$ before treatment and $+1.7 \pm 0.3 \%$ and $+0.7 \% \pm 0.3 \%$ after treatment $(P<0.001)$ during a mean of 2.8 years follow up

(C) The Author(s). 2019 Open Access This article is distributed under the terms of the Creative Commons Attribution 4.0 International License (http://creativecommons.org/licenses/by/4.0/), which permits unrestricted use, distribution, and 
time. In the recent study, Taveira-DaSilva et al. [9] evaluated the change of pulmonary function of 25 patients with sirolimus treatment, over a period of $4.5 \pm 1.6$ years, in which annual changes in forced expiratory volume in $1 \mathrm{~s}\left(\mathrm{FEV}_{1}\right)$ and diffusion capacity for carbon monoxide (DLCO) were reduced from $-7.4 \% \pm 1.4 \%$ to $-0.3 \% \pm$ $0.5 \% \quad(P<0.001)$ and $-6.4 \% \pm 0.9 \%$ to $-0.4 \% \pm 0.5 \%$ $(P<0.001)$, respectively. Johnson et al. $[10,11]$ prospectively observed LAM patients treated with sirolimus over 2 years, the mean change in $\mathrm{FEV}_{1}$ ranged from $7 \pm 82 \mathrm{ml} /$ year $(n=23)$ to $11 \pm 75 \mathrm{ml} /$ year $(n=47)$. The above studies demonstrated that sirolimus effectively improves the lung function in LAM patients. However, it is still unknown whether sirolimus continuously improves or stabilizes lung function over a longer observation period.

Considering sirolimus is used in LAM patients for a long period of time, whether its efficacy can be maintained is a critical question. Safety is another issue for those patients who take sirolimus for many years. In this study, we analyzed the efficacy and safety of sirolimus for up to 4 years.

\section{Method}

\section{Study populations}

Subjects were from the LAM registry in Peking Union Medical College Hospital (PUMCH), Beijing, China. The diagnosis of LAM was re-evaluated and confirmed according to the recent diagnosis criteria of American Thoracic Society and Japanese Respiratory Society published in 2017 [13]. Subjects were included if the following criteria were met: (1) sirolimus therapy with followup data after treatment, and (2) sirolimus therapy with baseline evaluation (within 3 months of sirolimus initiation). The exclusion criteria included the following: (1) patients with tuberous sclerosis complex, and (2) patients with other malignant tumors, and (3) patients who had undergone lung transplantation. Patients with tuberous sclerosis complex were not included because of limited data of this group of patients.

The protocol of this study was approved by the Ethical Committee of PUMCH (S-K709). All subjects included in this study signed informed consent documents.

The indication of sirolimus was primarily based on reduced lung function (FEV1 less than $70 \%$ predicted value) or rapidly declining lung function (FEV1 loss over $90 \mathrm{ml}$ per year) [5]. Other indications included chylothorax, chylous ascites, angiomyolipomas or repeated pneumothorax, etc. Dosage and dosage adjustment of sirolimus were based on the judgement of the physicians who treated the patient, which have been described in our previous study [6]. Generally, patients took sirolimus 1 or $2 \mathrm{mg}$ orally once daily. A serum level of 5 to $10 \mathrm{ng} /$ $\mathrm{ml}$ sirolimus was considered optimal concentration range. For patients with a serum level $>10 \mathrm{ng} / \mathrm{ml}$ or $<5$ $\mathrm{ng} / \mathrm{ml}$, the dose of sirolimus was adjusted according to the clinical symptoms and adverse events.

\section{Study design}

We carefully collected the annual follow-up records of the enrolled subjects for this retrospective analysis. The follow-up visit data comprised pulmonary function tests, arterial blood gas analysis at rest (on room air), 6MWD, Borg dyspnea index, SGRQ, and VEGF-D. The baseline data were defined as those collected within 3 months of sirolimus initiation. The additional data were categorized as pretreatment and posttreatment data, defined as 1 year ( \pm 3 months) or 2 years ( \pm 3 months) before sirolimus initiation and 1 year ( \pm 3 months), 2 years $( \pm 3$ months), 3 years ( \pm 3 months), and 4 years ( \pm 3 months) after sirolimus initiation.

Pulmonary function was measured according to the American Thoracic Society/European Respiratory Society (ATS/ERS) Task Force Standardization of Lung Function Testing [14]. The 6MWD was performed based on ATS guidelines [15]. Borg dyspnea index was assessed at the end of the 6MWD test. Patients completed the SGRQ according to the provided instructions. The pneumothorax and chylothorax were evaluated by chest X-ray or CT. Degree of pulmonary cystic lesions and renal angiomyolipoma size was evaluated by $\mathrm{CT}$. Adverse events were assessed according to the Common Terminology Criteria for Adverse Events (version 3.0). Serum VEGF-D levels were measured with an enzymelinked immunosorbent assay (Quantikinine Human VEGF-D Immunoassay, R\&D Systems).

\section{Statistical analysis}

Normally distributed data are reported as the mean \pm SD; data that were not normally distributed are reported as the medians and interquartile ranges (median [25, $75 \%])$. The normality of the data was analyzed by the Kolmogorov-Smirnov test. The unpaired $t$-test or MannWhitney $U$-test was used to compare continuous variables. The paired $t$-test was used to compare the baseline data with post-treatment data. All reported $P$ values are two-sided. $P$ values less than 0.05 were considered statistically significant. We used $R$ language V3.5.3 (Microsoft, Washington, USA) to build linearmix-effect model in order to assess the effects of sirolimus therapy. Data analyses were also performed in GraphPad Prism V.7.03 (Graphpad, California, USA) and SPSS V.24 (IBM, New York, USA).

\section{Results}

\section{Demographics}

The baseline characteristics and clinical features of the study participants $(n=142)$ are shown in Table 1 . Of 
142 subjects enrolled, 122, 83, 60 and 32 patients were followed-up for 1, 2, 3 and 4 years respectively.

\section{Sirolimus improves pulmonary function, oxygen levels, exercise capacity and quality of life}

Not surprisingly, in comparison to the pretreatment data, the posttreatment data showed that sirolimus significantly improved pulmonary function $\left(\mathrm{FEV}_{1}, \mathrm{FEV}_{1} \%\right.$ predicted, FVC, FVC\%predicted, $\mathrm{FEV}_{1} / \mathrm{FVC}$, DLCO), oxygen levels $\left(\mathrm{PaO}_{2}, \mathrm{P}(\mathrm{A}-\mathrm{a}) \mathrm{O}_{2}\right), 6 \mathrm{MWD}$, SGRQ and VEGF-D levels (Table 2). Over a mean duration of $1.4 \pm$ 0.5 years before the beginning of sirolimus therapy, the $\mathrm{FEV}_{1}$ decreased by $178 \pm 36 \mathrm{ml}$ per year $(7.71 \% \pm 1.20 \%$ predicted, $P<0.001)$, and the FVC decreased by $-72 \pm$ $68 \mathrm{ml}$ per year $(-4.11 \% \pm 1.15 \%$ predicted, $P<0.001)$. In contrast, over a mean of $2.2 \pm 1.1$ years of sirolimus therapy, the $\mathrm{FEV}_{1}$ changed by $-10 \pm 15 \mathrm{ml}$ per year $(0.29 \% \pm$ $0.48 \%$ predicted, $P>0.05$ ), and the FVC increased by $54 \pm 22 \mathrm{ml}$ per year $(2.78 \% \pm 0.72 \%$ predicted, $P<0.001)$.

\section{Pulmonary function changes in patients with chylothorax and those without chylothorax}

Forty-eight patients were with chylothorax, and $94 \mathrm{pa}-$ tients were without chylothorax. Pulmonary function data were only available in patients with small amount of pleural effusion. Our data showed that baseline VEGF-D levels were higher in patients with chylothorax, however no significant differences were observed in changes of VEGF-D levels and pulmonary functions in patients with and without chylothorax over 4 years treatment (data not shown). The yearly changes of $\mathrm{FEV}_{1}$ in patients with and without chylothorax were $0.46 \% \pm$ $0.76 \%$ predicted and $0.10 \% \pm 0.60$ predicted $(P=0.95)$, respectively. The yearly change of DLco were $-0.06 \% \pm$ $0.69 \%$ and $-0.45 \% \pm 0.43 \%$ predicted $(P=0.92)$.

\section{Long-term effects of sirolimus at 1, 2, 3 and 4 years}

The main aim of the study was to investigate the longterm effects of sirolimus. Using paired comparison, we were able to detect the differences of the measurements from the baseline to 1,2, 3 and 4 years after the initiation of treatment. As shown in Table 3, the $\mathrm{FEV}_{1}$ improved significantly in the first year, and the FVC improved in the first and second year; then, the significance disappeared during the subsequent follow-up. There were no changes in the diffusion capacity after treatment. Overall, pulmonary function was maintained after the initiation of sirolimus therapy. Sirolimus could potentially stabilize pulmonary function for up to 4 years. The improvements in $\mathrm{PaO}_{2}, \mathrm{P}(\mathrm{A}-\mathrm{a}) \mathrm{O}_{2}, 6 \mathrm{MWD}$, and SGRQ were maintained for 3 years and disappeared in the fourth year (Table 3). No worsening was observed except for in $\mathrm{FEV}_{1} / \mathrm{FVC}$ during the follow-up period. The decrease in VEGF-D level was maintained for up to
Table 1 Baseline demographic and clinical features of patients with lymphangioleiomyomatosis

\begin{tabular}{|c|c|c|}
\hline Demographics & Numbers & Percentage or value \\
\hline Total sample size & 142 & $100 \%$ \\
\hline Age (years) & & $38 \pm 9$ \\
\hline \multicolumn{3}{|l|}{ Sex } \\
\hline Female & 142 & $100 \%$ \\
\hline Former smoker & 0 & $0 \%$ \\
\hline \multicolumn{3}{|l|}{ Complications } \\
\hline Renal angiomyolipomas & $33 / 142$ & $23.2 \%$ \\
\hline Pneumothorax & $40 / 142$ & $28.2 \%$ \\
\hline Chylothorax & $48 / 142$ & $33.8 \%$ \\
\hline Chyloperitoneum & $16 / 142$ & $11.3 \%$ \\
\hline \multicolumn{3}{|l|}{ CT grading ${ }^{a}$} \\
\hline 1 & $7 / 142$ & $4.9 \%$ \\
\hline$\|$ & $9 / 142$ & $6.3 \%$ \\
\hline III & $119 / 142$ & $83.8 \%$ \\
\hline \multicolumn{3}{|l|}{ Pulmonary function } \\
\hline $\mathrm{FEV}_{1}(\mathrm{ml})$ & 114 & $1622 \pm 712$ \\
\hline FVC (ml) & 114 & $2760 \pm 645$ \\
\hline $\mathrm{FEV}_{1} \%$ pred & 114 & $58.5 \pm 25$ \\
\hline FVC\% pred & 114 & $85 \pm 20.6$ \\
\hline $\mathrm{FEV}_{1} / \mathrm{FVC}(\%)$ & 114 & $57.5 \pm 17.9$ \\
\hline RV\% pred & 107 & $161.3 \pm 79.3$ \\
\hline TLC\% pred & 107 & $116.8 \pm 103.8$ \\
\hline $\mathrm{RV} / \mathrm{TLC}(\%)$ & 107 & $46.25 \pm 13.67$ \\
\hline DLCO\% pred $(N=107)$ & 107 & $40.7 \pm 21.2$ \\
\hline \multicolumn{3}{|l|}{ Arterial blood gas analysis } \\
\hline $\mathrm{PaO}_{2}(\mathrm{mmHg})$ & 122 & $72.3 \pm 13.4$ \\
\hline $\mathrm{P}(\mathrm{A}-\mathrm{a}) \mathrm{O}_{2}(\mathrm{mmHg})$ & 114 & $43.4 \pm 51.1$ \\
\hline Borg dyspnea index & 132 & $2.5 \pm 2.1$ \\
\hline 6MWD (m) & 133 & $422 \pm 113$ \\
\hline SGRQ & 132 & \\
\hline Symptoms score & 132 & $40.4 \pm 24.2$ \\
\hline Activity score & 132 & $54.2 \pm 24.9$ \\
\hline Impacts score & 132 & $40.5 \pm 25.8$ \\
\hline Total score & 132 & $44.8 \pm 23.5$ \\
\hline Serum VEGF-D level (pg/ml) & 140 & $3318 \pm 2578$ \\
\hline
\end{tabular}

Data: mean \pm SD

Abbreviations: 6MWD 6-min walking distance, DLCO Diffusion capacity for carbon monoxide, FEV ${ }_{1}$ Forced expiratory volume in 1 second; FVC Forced vital capacity, $\mathrm{PaO}_{2}$ Partial pressure of oxygen; $\mathrm{P}(\mathrm{A}-a) \mathrm{O}_{2}$ Alveolo-arterial oxygen partial pressure difference, $R V$ Residual volume, SGRQ St.George's Respiratory Questionnaire, TLC Total lung capacity, VEGF-D Vascular endothelial growth factor-D. ${ }^{\text {a }}$ : According to the degree of lung involvement, $C T$ was classified as I, II and III grades. Grade I was less than $1 / 3$ of the whole lung field, Grade III was more than $2 / 3$, Grade II was between $1 / 3$ and $2 / 3$ [16] 
Table 2 Changes in pulmonary function and other indicators per year before and after sirolimus treatment

\begin{tabular}{|c|c|c|c|c|c|}
\hline \multirow[t]{2}{*}{ Variables } & \multicolumn{2}{|l|}{ Before treatment } & \multicolumn{2}{|l|}{ After treatment } & \multirow{2}{*}{$\begin{array}{l}\text { Before vs. Afte } \\
P \text { value }\end{array}$} \\
\hline & Mean change per year & ${ }^{\S} p$ value & Mean change per year & ${ }^{5} P$ value & \\
\hline$\overline{\mathrm{FEV}} \mathrm{V}_{1}(\mathrm{ml})$ & $-178 \pm 36$ & $<0.001$ & $-10 \pm 15$ & 0.53 & $<0.001$ \\
\hline $\mathrm{FVC}(\mathrm{ml})$ & $-72 \pm 68$ & 0.29 & $54 \pm 22$ & 0.016 & 0.017 \\
\hline $\mathrm{FEV}_{1} \%$ pred & $-7.71 \pm 1.20$ & $<0.001$ & $0.29 \pm 0.48$ & 0.42 & $<0.001$ \\
\hline FVC\%pred & $-4.11 \pm 1.15$ & 0.009 & $2.78 \pm 0.72$ & $<0.001$ & 0.008 \\
\hline $\mathrm{FEV}_{1} / \mathrm{FVC}(\%)$ & $-7.34 \pm 1.08$ & $<0.001$ & $-1.40 \pm 0.40$ & $<0.001$ & $<0.001$ \\
\hline DLCO\%pred & $-4.12 \pm 1.10$ & 0.002 & $-0.32 \pm 0.37$ & 0.40 & 0.017 \\
\hline $\mathrm{PaO}_{2}(\mathrm{mmHg})$ & $-5.7 \pm 1.3$ & $<0.001$ & $1.8 \pm 0.5$ & $<0.001$ & 0.002 \\
\hline $\mathrm{P}(\mathrm{A}-\mathrm{a}) \mathrm{O}_{2}(\mathrm{mmHg})$ & $4.5 \pm 1.3$ & 0.002 & $-1.3 \pm 0.5$ & 0.012 & 0.002 \\
\hline $6 \mathrm{MWD}(\mathrm{m})$ & $-21 \pm 6$ & $<0.001$ & $15 \pm 3$ & $<0.001$ & $<0.001$ \\
\hline SGRQ total score & $3.29 \pm 2.02$ & 0.11 & $-2.65 \pm 0.68$ & $<0.001$ & $<0.001$ \\
\hline VEGF-D (pg/ml) & $-233 \pm 185$ & 0.22 & $-555 \pm 96$ & $<0.001$ & $<0.001$ \\
\hline
\end{tabular}

Data: mean \pm SD. Data were obtained by using mixed-effects models. ${ }^{5} P$ was calculated against a slope $=0 .{ }^{n} P$ was calculated by the slope before sirolimus therapy versus the slope after sirolimus therapy

Table 3 Paired comparisons of functional tests and serum VEGF-D levels between the baseline and annual time points during sirolimus treatment

\begin{tabular}{|c|c|c|c|c|c|c|c|c|c|c|c|c|}
\hline \multirow[t]{2}{*}{ Variable } & \multicolumn{3}{|l|}{1 year } & \multicolumn{3}{|l|}{2 years } & \multicolumn{3}{|l|}{3 years } & \multicolumn{3}{|l|}{4 years } \\
\hline & Baseline & $\begin{array}{l}\text { After } \\
\text { sirolimus }\end{array}$ & $P$ value & Baseline & $\begin{array}{l}\text { After } \\
\text { sirolimus }\end{array}$ & $P$ value & Baseline & $\begin{array}{l}\text { After } \\
\text { sirolimus }\end{array}$ & $P$ value & Baseline & $\begin{array}{l}\text { After } \\
\text { sirolimus }\end{array}$ & $P$ value \\
\hline $\begin{array}{l}\text { Pulmonary ventilation } \\
\text { function }\end{array}$ & $N=67$ & & & $N=36$ & & & $N=22$ & & & $N=11$ & & \\
\hline $\mathrm{FEV}_{1}(\mathrm{ml})$ & $\begin{array}{l}1590 \pm \\
690\end{array}$ & $1640 \pm 710$ & 0.045 & $\begin{array}{l}1640 \pm \\
610\end{array}$ & $1610 \pm 690$ & 0.462 & $\begin{array}{l}1470 \pm \\
660\end{array}$ & $1520 \pm 740$ & 0.560 & $\begin{array}{l}1440 \pm \\
590\end{array}$ & $1310 \pm 440$ & 0.099 \\
\hline FVC (ml) & $\begin{array}{l}2640 \pm \\
760\end{array}$ & $2830 \pm 700$ & 0.004 & $\begin{array}{l}2700 \pm \\
620\end{array}$ & $2880 \pm 560$ & 0.044 & $\begin{array}{l}2680 \pm \\
660\end{array}$ & $2780 \pm 630$ & 0.398 & $\begin{array}{l}2570 \pm \\
560\end{array}$ & $2800 \pm 380$ & 0.149 \\
\hline $\mathrm{FEV}_{1} \%$ pred & $\begin{array}{l}55.97 \pm \\
23.75\end{array}$ & $59.28 \pm 24.3$ & 0.004 & $\begin{array}{l}57.48 \pm \\
21.97\end{array}$ & $58.28 \pm 24.6$ & 0.705 & $54.22 \pm 23$ & $\begin{array}{l}57.02 \pm \\
26.44\end{array}$ & 0.346 & $\begin{array}{l}50.38 \pm \\
21.09\end{array}$ & $\begin{array}{l}49.19 \pm \\
17.75\end{array}$ & 0.557 \\
\hline FVC\%pred & $\begin{array}{l}80.85 \pm \\
22.37\end{array}$ & $\begin{array}{l}87.87 \pm \\
24.06\end{array}$ & 0.005 & $\begin{array}{l}83.2 \pm \\
17.94\end{array}$ & $\begin{array}{l}89.68 \pm \\
18.03\end{array}$ & 0.019 & $\begin{array}{l}83.56 \pm \\
22.27\end{array}$ & $\begin{array}{l}92.08 \pm \\
22.08\end{array}$ & 0.054 & $\begin{array}{l}81.32 \pm \\
18.72\end{array}$ & $90.84 \pm 15.3$ & 0.128 \\
\hline $\mathrm{FEV}_{1} / \mathrm{FVC}$ & $\begin{array}{l}56.27 \pm \\
17.42\end{array}$ & $\begin{array}{l}56.33 \pm \\
18.02\end{array}$ & 0.966 & $\begin{array}{l}58.32 \pm \\
20.66\end{array}$ & $\begin{array}{l}53.72 \pm \\
21.82\end{array}$ & 0.000 & $\begin{array}{l}53.59 \pm \\
22.1\end{array}$ & $\begin{array}{l}52.94 \pm \\
23.07\end{array}$ & 0.812 & $\begin{array}{l}54.04 \pm \\
19.9\end{array}$ & $\begin{array}{l}45.25 \pm \\
15.17\end{array}$ & 0.014 \\
\hline Gas exchange & $N=48$ & & & $N=26$ & & & $N=19$ & & & $N=7$ & & \\
\hline DLCO\%pred & $\begin{array}{l}40.62 \pm \\
20.34\end{array}$ & $\begin{array}{l}41.23 \pm \\
20.42\end{array}$ & 0.378 & $\begin{array}{l}46.94 \pm \\
23.87\end{array}$ & $\begin{array}{l}45.23 \pm \\
22.26\end{array}$ & 0.197 & $\begin{array}{l}32.86 \pm \\
19.01\end{array}$ & $\begin{array}{l}35.64 \pm \\
16.91\end{array}$ & 0.104 & $\begin{array}{l}34.46 \pm \\
17.65\end{array}$ & $\begin{array}{l}30.49 \pm \\
12.71\end{array}$ & 0.109 \\
\hline Arterial blood gas & $N=69$ & & & $N=39$ & & & $N=31$ & & & $N=17$ & & \\
\hline $\mathrm{PaO}_{2}(\mathrm{mmHg})$ & $\begin{array}{l}66.99 \pm \\
12.58\end{array}$ & $\begin{array}{l}71.21 \pm \\
14.98\end{array}$ & 0.006 & $\begin{array}{l}68.14 \pm \\
12.61\end{array}$ & $75.68 \pm 16.5$ & $\begin{array}{l}< \\
0.001\end{array}$ & $\begin{array}{l}66.34 \pm \\
10.68\end{array}$ & $\begin{array}{l}70.63 \pm \\
13.36\end{array}$ & 0.026 & $\begin{array}{l}69.24 \pm \\
9.662\end{array}$ & $\begin{array}{l}74.09 \pm \\
11.02\end{array}$ & 0.084 \\
\hline $\mathrm{P}(\mathrm{A}-\mathrm{a}) \mathrm{O}_{2}(\mathrm{mmHg})$ & $\begin{array}{l}41.29 \pm \\
13.51\end{array}$ & $\begin{array}{l}36.67 \pm \\
16.07\end{array}$ & 0.013 & $\begin{array}{l}40.6 \pm \\
13.28\end{array}$ & $\begin{array}{l}32.97 \pm \\
17.23\end{array}$ & $\begin{array}{l}< \\
0.001\end{array}$ & $\begin{array}{l}42.63 \pm \\
12.13\end{array}$ & $\begin{array}{l}36.76 \pm \\
13.89\end{array}$ & 0.007 & $\begin{array}{l}37.89 \pm \\
12.72\end{array}$ & $35.61 \pm 11.6$ & 0.504 \\
\hline 6-min walk test & $N=67$ & & & $N=34$ & & & $N=27$ & & & $N=12$ & & \\
\hline $6 \mathrm{MWD}(\mathrm{m})$ & $417 \pm 122$ & $461 \pm 105$ & $\begin{array}{l}< \\
0.001\end{array}$ & $420 \pm 120$ & $472 \pm 98$ & $\begin{array}{l}< \\
0.001\end{array}$ & $408 \pm 105$ & $459 \pm 107$ & 0.004 & $379 \pm 145$ & $436 \pm 96$ & 0.1572 \\
\hline SGRQ & $N=63$ & & & $N=33$ & & & $N=27$ & & & $N=12$ & & \\
\hline Total score & $\begin{array}{l}46.11 \pm \\
22.11\end{array}$ & $38.37 \pm 22$ & $\begin{array}{l}< \\
0.001\end{array}$ & $\begin{array}{l}42.85 \pm \\
21.83\end{array}$ & $\begin{array}{l}31.21 \pm \\
21.79\end{array}$ & $\begin{array}{l}< \\
0.001\end{array}$ & $\begin{array}{l}48.04 \pm \\
23.24\end{array}$ & $\begin{array}{l}38.93 \pm \\
21.94\end{array}$ & 0.0078 & $\begin{array}{l}53.25 \pm \\
24.51\end{array}$ & $\begin{array}{l}49.08 \pm \\
21.95\end{array}$ & 0.5019 \\
\hline Serum VEGF-D level & $N=89$ & & & $N=50$ & & & $N=34$ & & & $N=15$ & & \\
\hline VEGF-D (pg/ml) & $\begin{array}{l}3594 \pm \\
3156\end{array}$ & $\begin{array}{l}2001 \pm \\
1972\end{array}$ & $\begin{array}{l}< \\
0.001\end{array}$ & $\begin{array}{l}3711 \pm \\
3714\end{array}$ & $\begin{array}{l}2133 \pm \\
2550\end{array}$ & $\begin{array}{l}< \\
0.001\end{array}$ & $\begin{array}{l}3280 \pm \\
2228\end{array}$ & $\begin{array}{l}1761 \pm \\
1255\end{array}$ & $\begin{array}{l}< \\
0.001\end{array}$ & $\begin{array}{l}3445 \pm \\
2453\end{array}$ & $\begin{array}{l}1851 \pm \\
1355\end{array}$ & $\begin{array}{l}< \\
0.001\end{array}$ \\
\hline
\end{tabular}


4 years (Table 3). For chylothorax, one patient accepted thoracic duct surgery and sirolimus treatment at the same time and rapidly achieved a complete remission. Among the patients receiving sirolimus treatment without surgery, 35 patients got complete remission, and 12 patients improved.

\section{Dosage of sirolimus}

The mean dosage of sirolimus was $1.59 \pm 0.50 \mathrm{mg} / \mathrm{d}$ (range, 1 to $2 \mathrm{mg} / \mathrm{d}$ ) at the beginning, and it was $1.27 \pm$ $0.47 \mathrm{mg} / \mathrm{d}$ (range, 0.5 to $2 \mathrm{mg} / \mathrm{d}$ ) after an adjustment period of 1-6 months. Ninety patients accepted the tests of the serum concentration of sirolimus in the first year. The average blood sirolimus level was $7.2 \pm 2.6 \mathrm{ng} / \mathrm{ml}$ (range, 1.5 to $18.6 \mathrm{ng} / \mathrm{ml}$ ).

\section{Frequencies of adverse events}

The adverse events that occurred in our study during the observation period are listed in Table 4. In the first year, the most frequent adverse events were mouth ulcer (68.2\%), menstrual abnormality (57.9\%), acne (34.6\%), weakness (11\%), diarrhea (6\%), and peripheral edema (5.6\%). During the next 3 years, the common adverse events were mouth ulcer, menstrual abnormality and acne. However, the incidence rate of mouth ulcer, menstrual abnormality and acne reduced to $23.3,26.7$ and $10 \%$ in the fourth year. Occurrence of adverse events could reduce over time (Table 4). We did not observe severe adverse events in our follow-up periods. Three patients required the temporary discontinuation of sirolimus therapy due to menstrual abnormalities, and then restarted the therapy after 3 to 6 months. No other patients had to discontinue sirolimus therapy because of adverse events.

\section{Discussion}

Whether the efficacy of sirolimus can be maintained during long-term treatment is a critical question. We

Table 4 Adverse events while taking sirolimus according to the duration of treatment in patients with LAM

\begin{tabular}{|c|c|c|c|c|}
\hline \multirow{2}{*}{$\begin{array}{l}\text { Time after sirolimus } \\
\text { (years) }\end{array}$} & \multicolumn{4}{|l|}{ Number (\%) } \\
\hline & Year $1(N=107)$ & Year $2(N=70)$ & Year $3(N=53)$ & Year $4(N=30)$ \\
\hline Mouth ulcer & $73(68.2)$ & $33(47.1)$ & $22(41.5)$ & $7(23.3)$ \\
\hline Menstrual abnormality & $62(57.9)$ & $34(48.6)$ & $16(30.2)$ & $8(26.7)$ \\
\hline Acne & $37(34.6)$ & $22(31.4)$ & $12(22.6)$ & $3(10.0)$ \\
\hline Ovarian cysts ${ }^{\mathrm{a}}$ & 17/55 (30.9) & 10/37 (27.0) & $6 / 25(24.0)$ & $1 / 8(12.5)$ \\
\hline Weakness & $11(10)$ & $1(1.4)$ & 0 & 0 \\
\hline Peripheral edema & $6(5.6)$ & $2(2.9)$ & $1(1.9)$ & $1(3.3)$ \\
\hline Diarrhea & $6(5.6)$ & $1(1.4)$ & 0 & 0 \\
\hline Rash & $5(4.7)$ & 0 & 0 & $1(3.3)$ \\
\hline Nausea & $5(4.7)$ & 0 & $1(1.9)$ & 0 \\
\hline Weight loss & $5(4.7)$ & 0 & 0 & 0 \\
\hline Arthralgia & $4(3.7)$ & 0 & 0 & $1(3.3)$ \\
\hline Abdominal pain & $3(2.8)$ & $2(2.9)$ & 0 & 0 \\
\hline Pruritus & $3(2.8)$ & $1(1.4)$ & 0 & 0 \\
\hline Abdominal distention & $2(1.9)$ & 0 & 0 & 0 \\
\hline Fever & $2(1.9)$ & 0 & 0 & 0 \\
\hline Chest pain & $2(1.9)$ & $1(1.4)$ & $1(1.9)$ & $1(3.3)$ \\
\hline Toothache & $1(0.9)$ & 0 & 0 & 0 \\
\hline Gingival hyperplasia & $1(0.9)$ & 0 & 0 & 0 \\
\hline Periodontitis & $1(0.9)$ & 0 & 0 & 0 \\
\hline Herpes zoster & $1(0.9)$ & $1(1.4)$ & 0 & 0 \\
\hline Alopecia & $1(0.9)$ & 0 & 0 & 0 \\
\hline Headache & $1(0.9)$ & 0 & 0 & 0 \\
\hline Dizziness & $1(0.9)$ & 0 & 0 & 0 \\
\hline Palpitation & $1(0.9)$ & 0 & 0 & 0 \\
\hline Myalgia & $1(0.9)$ & 0 & 0 & 0 \\
\hline Tenosynovitis & $1(0.9)$ & 0 & 0 & 0 \\
\hline
\end{tabular}


partially answered this question in the present study. We found improvements of sirolimus in the following parameters in patients after beginning sirolimus treatment: the $\mathrm{FEV}_{1}$ in the first year; the FVC in the first and second year; arterial oxygen levels, exercise capacity and quality of life in the first, second and third year; and the VEGF-D levels in all 4 years. An encouraging finding was that most measurements improved or stabilized during 4-year observations after sirolimus treatment.

Current clinical trials usually observed $12-24$ months of sirolimus treatment. Several studies included observations over 2 years. In studies with 2-4 years observation, the increase in the $\mathrm{FEV}_{1}$ varied from $11 \mathrm{ml} /$ year to 50 $\mathrm{ml} /$ year after starting sirolimus treatment $[6,7,10-12]$. In a 4-year prospective study, the mean change in the $\mathrm{FEV}_{1}$ in patients not receiving sirolimus was $-70 \mathrm{ml} /$ year $(n=66)$, while the mean change in patients receiving sirolimus was $7 \mathrm{ml} /$ year $(n=23)$ [10]. Taveira-DaSilva et al. [9] observed 25 patients for 4.5 years, and the $\mathrm{FEV}_{1}$ and DLCO changed slightly. The change of $\mathrm{FEV}_{1}$ was -10 $\mathrm{ml} /$ year $(P=0.53)$ and the $\mathrm{FVC}$ increased by $54 \mathrm{ml} /$ year $(P=0.016)$ in our study. In the paired comparison analysis, we found that the $\mathrm{FEV}_{1}$ benefited most from sirolimus in the first year, and the FVC benefited in the first 2 years. No significant reduction in pulmonary function was observed over the 4 years. The efficacy of sirolimus can be maintained for at least 4 years.

Higher VEGF-D levels were observed more frequently in patients with lymphatic disease who presented with chylous pleural effusion or ascites than in patients without lymphatic involvement [17]. Several studies reported that compared with patients without lymphatic disease, patients with lymphatic involvement may experience a great improvement in pulmonary function after starting sirolimus therapy [7, 9]. Taveira-DaSilva et al. [9] observed that the effects of sirolimus on VEGF-D levels and DLCO were especially marked in patients with LAM with lymphatic involvement than those without lymphatic involvement. For patients with or without limited small amount of chylothorax, improvement of pulmonary function was similar.

The safety profile is satisfactory. Patients tolerated sirolimus treatment very well. The rate of adverse effects decreased during the follow-up. We also analyzed the group of patients who were followed up for 3 and 4 years, the rate of adverse effects were decreased over time (data not shown).

Anyway, we still need to be cautious in observing long-term adverse effects from the treatment. LAM patients use sirolimus for many years, and it is important to monitor their progress and safety data regularly, at least once a year. Novel therapies for LAM are urgently needed for use when sirolimus cannot be used because of insensitivity or resistance of sirolimus.
The limitations of this study include its retrospective nature and the limited sample size during observation, as only 32 patients had data for all 4 years. Beginning in 2016, a national LAM registry in China was planned that will recruit 800 LAM patients and conduct yearly follow-up. We hope that some unanswered questions will be clarified in future studies.

In conclusion, sirolimus therapy is effective at improving or stabilizing pulmonary function, oxygen levels, exercise capacity, and quality of life in patients with LAM for up to 4 years. VEGF-D maintained at lower level for 4 years after the initiation of treatment. Adverse events related to sirolimus was mild during the follow-up period.

\section{Abbreviations}

\%pred: \% predicted; 6MWD: 6-min walking distance; ATS: American Thoracic Society; DLCO: Diffusion capacity for carbon monoxide; ERS: European

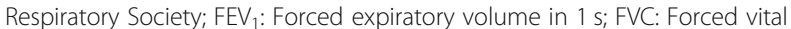
capacity; LAM: Lymphangioleiomyomatosis; $\mathrm{P}(\mathrm{A}-\mathrm{a}) \mathrm{O}_{2}$ : Alveolar-arterial oxygen gradient; $\mathrm{PaO}_{2}$ : Partial pressure of oxygen in arterial blood; RV: Residual volume; SGRQ: St. George's Respiratory Questionnaire; TLC: Total lung capacity; VEGF-D: Vascular endothelial growth factor-D

\section{Acknowledgements}

We thank Professor Feng Chen and Dr. Lijuan Lin from Nanjing Medical University for statistical assistance.

\section{Authors' contributions}

SH: study design, data analysis and manuscript writing. XW: study design, data analysis. WX: study design, data analysis. XT: clinical evaluation of the patients. YY: clinical evaluation of the patients. STW: clinical evaluation of the patients. SL: data analysis. XX: data analysis. KFX: design, clinical evaluation of the patients, data analysis, and manuscript writing. All authors read and approved the final manuscript.

\section{Funding}

This work was supported by the National Nature Science Foundation of China (81570061), the National Key Research and Development Program of China (2016YFC0901502), and Chinese Academy of Medical Sciences (CAMS) Initiative for Innovative Medicine (2017-12 M-2-001).

\section{Availability of data and materials}

The datasets used and analysed during the current study area available from the corresponding author.

\section{Ethics approval and consent to participate}

The study was part of LAM registry study of Peking Union Medical College Hospital (S-379). The protocol of this study was approved by the Ethical Committee of Peking Union Medical College Hospital (S-K709). All subjects included in this study signed informed consent documents.

\section{Consent for publication}

Consent for publication was obtained from all participants.

\section{Competing interests}

The authors declare that they have no competing interests.

\section{Author details}

${ }^{1}$ Department of Pulmonary and Critical Care Medicine, Peking Union Medical College Hospital, Chinese Academy of Medical Sciences, Peking Union Medical College, Beijing 100730, China. ${ }^{2}$ Department of Pulmonary and Critical Care Medicine, North of Jiangsu People's Hospital, Yangzhou 225001, China. ${ }^{3}$ Department of Respiratory Medicine, the Second Affiliated Hospital of Xiangya, Central South University, Changsha 410013, Hunan, China. ${ }^{4}$ Department of Pulmonary and Critical Care Medicine, Beijing Tiantan Hospital, Capital Medical University, Beijing 100050, China. ${ }^{5}$ Rare Diseases 
Research Center, Chinese Academy of Medical Sciences, Beijing, China. ${ }^{6}$ Central Laboratory, Peking Union Medical College Hospital, Chinese Academy of Medical Sciences, Peking Union Medical College, Beijing 100730, China.

Received: 3 April 2019 Accepted: 13 August 2019

Published online: 20 August 2019

\section{References}

1. Johnson SR, Taveira-DaSilva AM, Moss J. Lymphangioleiomyomatosis. Clin Chest Med. 2016:37(3):389-403.

2. Harari S, Torre O, Cassandro R, Moss J. The changing face of a rare disease: lymphangioleiomyomatosis. Eur Respir J. 2015;46(5):1471-85.

3. Henske EP, McCormack FX. Lymphangioleiomyomatosis - a wolf in sheep's clothing. J Clin Invest. 2012:122(11):3807-16.

4. McCormack FX, Inoue Y, Moss J, Singer LG, Strange C, Nakata K, et al. Efficacy and safety of sirolimus in lymphangioleiomyomatosis. N Engl J Med. 2011;364(17):1595-606.

5. McCormack FX, Gupta N, Finlay GR, Young LR, Taveira-DaSilva AM, Glasgow CG, et al. Official American Thoracic Society/Japanese respiratory society clinical practice guidelines: Lymphangioleiomyomatosis diagnosis and management. Am J Respir Crit Care Med. 2016;194(6):748-61.

6. Zhan Y, Shen L, Xu W, Wu X, Zhang W, Wang J, et al. Functional improvements in patients with lymphangioleiomyomatosis after sirolimus: an observational study. Orphanet J Rare Dis. 2018;13(1):34.

7. Taveira-DaSilva AM, Hathaway O, Stylianou M, Moss J. Changes in lung function and chylous effusions in patients with lymphangioleiomyomatosis treated with sirolimus. Ann Intern Med. 2011;154(12):797-805 W-292-3.

8. Taveira-DaSilva AM, Jones AM, Julien-Williams PA, Stylianou M, Moss J. Retrospective review of combined sirolimus and simvastatin therapy in lymphangioleiomyomatosis. Chest. 2015;147(1):180-7.

9. Taveira-DaSilva AM, Jones AM, Julien-Williams P, Stylianou M, Moss J. Longterm effect of Sirolimus on serum vascular endothelial growth factor D levels in patients with Lymphangioleiomyomatosis. Chest. 2018;153(1):124-32.

10. Bee J, Bhatt R, McCafferty I, Johnson SR. A 4-year prospective evaluation of protocols to improve clinical outcomes for patients with lymphangioleiomyomatosis in a national clinical Centre. Thorax. 2015;70(12): 1202-4.

11. Bee J, Fuller S, Miller S, Johnson SR. Lung function response and side effects to rapamycin for lymphangioleiomyomatosis: a prospective national cohort study. Thorax. 2018;73(4):369-75.

12. Yao J, Taveira-DaSilva AM, Jones AM, Julien-Williams P, Stylianou M, Moss J. Sustained effects of sirolimus on lung function and cystic lung lesions in lymphangioleiomyomatosis. Am J Respir Crit Care Med. 2014;190(11):1273-82.

13. Gupta N, Finlay GA, Kotloff RM, Strange C, Wilson KC, Young LR, et al. Lymphangioleiomyomatosis diagnosis and management: high-resolution chest computed tomography, Transbronchial lung biopsy, and pleural disease management. An official American Thoracic Society/Japanese respiratory society clinical practice guideline. Am J Respir Crit Care Med. 2017:196(10):1337-48.

14. Wanger J, Clausen JL, Coates A, Pedersen OF, Brusasco V, Burgos F, et al. Standardisation of the measurement of lung volumes. Eur Respir J. 2005; 26(3):511-22.

15. ATS Committee on Profiency Standards for Clinical Pulmonary Function Laboratories. ATS statement: guidelines for the six-minute walk test. Am J Respir Crit Care Med. 2002;166(1):111-7.

16. Avila NA, Dwyer AJ, Rabel A, Moss J. Sporadic lymphangioleiomyomatosis and tuberous sclerosis complex with lymphangioleiomyomatosis: comparison of CT features. Radiology. 2007;242(1):277-85.

17. Glasgow CG, Avila NA, Lin JP, Stylianou MP, Moss J. Serum vascular endothelial growth factor-D levels in patients with lymphangioleiomyomatosis reflect lymphatic involvement. Chest. 2009;135(5):1293-300.

\section{Publisher's Note}

Springer Nature remains neutral with regard to jurisdictional claims in published maps and institutional affiliations.

\section{Ready to submit your research? Choose BMC and benefit from:}

- fast, convenient online submission

- thorough peer review by experienced researchers in your field

- rapid publication on acceptance

- support for research data, including large and complex data types

- gold Open Access which fosters wider collaboration and increased citations

- maximum visibility for your research: over $100 \mathrm{M}$ website views per year

At BMC, research is always in progress.

Learn more biomedcentral.com/submissions 